\title{
ANALISIS KINERJA KEUANGAN DENGAN MENGGUNAKAN RASIO PROFITABILITAS DAN RASIO AKTIVITAS PADA PT BATA TBK
}

\author{
Ratningsih $^{1}$ dan Tuti Alawiyah ${ }^{2}$ \\ ${ }^{1}$ AMIK BSI Bogor \\ ${ }^{2}$ AMIK BSI Tasikmalaya \\ E-mail: ratningsih.rnn@bsi.ac.id dan tuti.tah@bsi.ac.id
}

\begin{abstract}
The purpose of this study was to analyze the financial performance of PT Bata Tbk by using profitability and activity ratios in the period of literature study. The research used the quantitative method and literature review. The research found that financial performances at PT Bata Tbk were less efficient. This could be seen in 2015's financial performance has increased while in 2014 and 2016 have decreased. PT Bata Tbk has failed in planning and developing its business strategy in an effort to obtain maximum profitability. Firm could not evaluate and measure performance standards that had been achieved on the basis of projected financial performance in the past, so that it could affect its customer loyalty and investor confidence levels. Meanwhile frequent fluctuations in the results which were achieved over a period of three years at PT Bata Tbk caused by unbalanced capital use, the management of its assets, and the imbalance between level of sales generated and suppressed cost. A slow inventory turnover rate and the low level of sales had leaded to lower profit level.
\end{abstract}

Keywords: Financial Performance, Profitability Rati, Activity Ratio

\section{PENDAHULUAN}

Setiap perusahaan atau organisasi di dalam menjalankan kegiatan bisnisnya pasti ingin mencapai tujuan perusahaan secara efektif dan efisien. Di dalam pencapaian tujuan perusahaan tersebut tidak terlepas dari yang namanya penggunaan dana perusahaan yang diperoleh dari modal yang dimiliki sendiri oleh perusahaan tersebut atau dari modal yang diperoleh dari pihak luar perusahaan dalam hal ini sering kita sebut sebagai modal asing.

Tolak ukur keberhasilan sebuah perusahaan atau maju mundurnya perusahaan bisa kita lihat dari laporan keuangan perusahaan. Berdasarkan laporan keuangan perusahaan yang telah dicapai dalam suatu periode tertentu kita dapat memperoleh informasi dengan jelas tingkat laba atau rugi yang telah dicapai perusahaan sehingga bisa dijadikan sebagai pertanggungjawaban manajemen perusahaan kepada pihak-pihak yang membutuhkan informasi keuangan tersebut. Pihak-pihak yang memiliki kepentingan ini terdiri dari internal perusahaan yaitu pemilik, karyawan, dan pihak eksternal perusahaan seperti para pemegang saham, investor, pemerintah, bahkan supplier.

Untuk dapat melihat seperti apa kinerja perusahaan yang telah dicapai dalam menjalankan kegiatan bisnisnya maka perlu dilakukan analisa laporan keuangan. Analisa laporan keuangan juga berguna untuk melihat kinerja yang dicapai dari waktu ke waktu sehingga bisa dijadikan sebagai dasar pengambilan keputusan. Ada beberapa alat analisis yang bisa digunakan untuk mengukur kinerja keuangan perusahaan. Dalam penelitian ini, alat analisis yang digunakan adalah kelompok rasio profitabilitas dan rasio aktivitas.

Rasio profitabilitas merupakan sebuah rasio yang digunakan untuk menilai kemampuan perusahaan menghasilkan laba dari pendapatan yang telah diperoleh 
berdasarkan penggunaan modal yang telah dilakukan. Rasio profitabilitas ini biasanya mengunakan beberapa alat test seperti gross profit margin yaitu suatu alat analisis atau rasio yang membandingkan antara laba kotor terhadap penjualan. Rasio lain yang digunakan yaitu net profit margin yang membandingkan antara laba bersih yang telah dicapai dengan tingkat penjualan yang sudah dilakukan. Selanjutnya return on investment yang menganalisis bagaimana kemampuan memperoleh laba dari total aktiva yang dimiliki oleh perusahaan.

Selain dimensi profitabilitas, seperti telah dikemukakan sebelumnya, penelitian ini juga menggunakan kelompok rasio aktivitas. Terkait dengan aktivitas ini, ada bebrapa alat analisis yang digunakan yaitu pertama, perputaran piutang yang diperoleh dengan cara membagi penjualan dengan rata-rata piutang. Rasio ini digunakan untuk mengetahui bagaimana kita dapat memperoleh atau menagih piutang dengan cepat. Rasio kedua yang digunakan adalah rasio perputaran persediaan. Rasio ini diperoleh dengan cara membagi antara harga pokok penjualan dengan rata-rata persediaan. Dan yang terakhir adalah rassio perputaran total aktiva yang mengukur perputaran dari semua aset yang dimiliki perusahaan.

Penelitian ini dilakukan di PT BATA Tbk, sebuah perusahaan yang memproduksi dan memasarkan bermacam jenis sandal dan sepatu untuk kalangan remaja, dewasa maupun anak anak. PT Sepatu Bata Tbk adalah anggota Bata Shop Organization (BSO) yang mempunyai kantor pusat di Lausanne, Swiss. BSO ini merupakan salah satu produsen terbesar penghasil sepatu di dunia yang beroperasi di banyak negara dan menghasilkan serta menjual jutaan pasang sepatu setiap tahunnya.

Sebagai produsen sepatu yang sangat besar dan memiliki pangsa pasar yang sangat luas serta begitu banyak pesaing yang bisa mengancam keadaan bisnis perusahaan, dirasa perlu untuk menganalisis bagaimana kinerja keuangan PT Bata Tbk guna meningkatkan efektifitas dan efisiensi perusahaannya. Dari segi laporan keuangan, penelitian ini menganalisis kinerja keuangan PT Bata Tbk dengan menggunakan rasio profitabilitas dan rasio aktivitas selama 4 tahun terakhir. Berikut beberapa gambaran mengenai elemen laporan keuangan PT Bata Tbk dari tahun 2013 sampai tahun 2016.

Tabel 1.

Total Aktiva, Laba Bersih, Dan Penjualan PT Bata Tbk

\begin{tabular}{|c|c|c|c|}
\hline Tahun & Penjualan & Total Aktiva & $\begin{array}{c}\text { Laba/Rugi } \\
\text { Bersih }\end{array}$ \\
\hline 2013 & 902.459 .209 & 680.685 .060 & 44.373 .679 \\
\hline 2014 & 1.008727 .515 & 774.891 .087 & 71.246 .429 \\
\hline 2015 & 1.028 .850 .578 & 795.257 .974 & 129.519 .446 \\
\hline 2016 & 999.802 .379 & 804.742 .917 & 42.231 .663 \\
\hline
\end{tabular}

Sumber : Laporan Keuangan PT Bata Tbk.

Dari Tabel 1 dapat dilihat bahwa penjualan selama 3 tahun dari tahun 2013 sampai dengan 2015 terjadi peningkatan penjualan namun pada tahun 2016 mengalami penurunan kembali. Total aktiva selama empat tahun terus mengalami peningkatan. Sedangkan laba bersih mengalami fluktuasi selama periode ini.

\section{KAJIAN LITERATUR}

\section{Pengertian Laporan Keuangan}

Menurut Kasmir (2013:7) dalam pengertian yang sederhana, laporan keuangan adalah laporan yang menunjukkan kondisi keuangan perusahaan pada saat ini atau dalam suatu periode tertentu. Maksud laporan keuangan yang menunjukkan kondisi keuangan perusahaan saat ini adalah merupakan kondisi terkini. Kondisi perusahaan terkini adalah keadaan keuangan perusahaan pada tanggal tertentu (untuk neraca) dan periode tertentu (untuk laporan laba rugi). Laporan keuangan menggambarkan pos-pos keuangan perusahaan yang diperoleh dalam suatu periode. Munawir (2010:5) menyatakan pada

JIMFE (Jurnal Ilmiah Manajemen Fakultas Ekonomi)

Volume 3 No. 2 Tahun 2017, Hal. 14-27 
umumnya laporan keuangan itu terdiri dari neraca dan perhitungan laba-rugi serta laporan perubahan ekuitas. Neraca menunjukkan atau menggambarkan jumlah aset, kewajiban dan ekuitas dari suatu perusahaan pada tanggal tertentu. Perhitungan (laporan) laba-rugi memperlihatkan hasil-hasil yang telah dicapai oleh perusahaan dan beban yang terjadi selama periode tertentu. Sedangkan laporan perubahan ekuitas menunjukkan sumber dan penggunaan atau alasan-alasan yang menyebabkan perubahan ekuitas perusahaan.

Harahap (2009:105) menjelaskan laporan keuangan menggambarkan kondisi keuangan dan hasil usaha suatu perusahaan pada saat tertentu atau jangka waktu tertentu. Adapun jenis laporan keuangan yang lazim dikenal adalah neraca (laporan posisi keuangan), laporan laba-rugi atau hasil usaha, laporan perubahan ekuitas, dan laporan arus kas. Senada dengan ini, Brigham dan Houston (2010) menambahkan bahwa laporan keuangan adalah beberapa lembar kertas dengan angka-angka yang tertulis diatasnya tetapi penting juga untuk memikirkan aset-aset nyata yang berada dibalik angka tersebut. Hal ini diperkuat oleh pendapat dari Subramanyam (2010) yang menyatakan bahwa laporan keuangan merupakan produk proses laporan keuangan yang diatur oleh standar dan aturan akuntansi, insentif manajer, serta mekanisme pelaksanaan dan pengawasan perusahaan. Pemahaman mengenai lingkungan pelaporan keuangan perlu disertai pemahaman tujuan dan konsep yang mendasari informasi akuntansi yang disajikan dalam laporan keuangan. Pengetahuan ini akan membantu dalam melihat posisi keuangan yang sesungguhnya dan kinerja perusahaan dengan lebih baik.

Di sisi lain, Fahmi (2011) mengatakan laporan keuangan merupakan suatu informasi yang menggambarkan kondisi suatu perusahaan, yang selanjutnya akan menjadi suatu informasi yang menggambarkan tentang kinerja suatu perusahaan.

Dari definisi-definisi di atas, dapat disimpulkan bahwa laporan keuangan adalah laporan yang menyajikan informasi yang akan digunakan oleh pihak pihak yang berkepentingan dengan posisi keuangan perusahaan, kinerja perusahaan, perubahan ekuitas, dan arus kas serta informasi lain yang merupakan hasil dari proses akuntansi selama periode akuntansi dari suatu kesatuan usaha.

\section{Jenis-Jenis Laporan keuangan}

Laporan keuangan yang disusun oleh manajemen perusahaan terdiri dari:

1. Laporan Posisi Keuangan

Informasi mengenai posisi keuangan perusahaan pada saat tertentu terutama disajikan dalam neraca (balance sheet). Neraca mempunyai tiga unsur laporan keuangan yaitu aset, liabilitas, dan ekuitas. Aset adalah sumber daya yang dikuasai oleh perusahaan sebagai akibat dari peristiwa masa lalu dan dari mana manfaat ekonomik di masa depan diharapkan akan diperoleh di masa depan (IAI,2015). Darsono (2005:19) berpendapat bahwa kewajiban adalah hak dari pemberi hutang (kreditor) terhadap kekayaan perusahaan, sedangkan ekuitas adalah hak pemilik atas kekayaan perusahaan. Pembagian dalam sisi kewajiban dan ekuitas dalam neraca adalah:
a. Kewajiban jangka pendek
b. Kewajiban jangka panjang
c. Ekuitas

2. Laporan Laba Rugi

Informasi mengenai kinerja perusahaan terutama disediakan dalam laporan laba rugi (income statement). Informasi kinerja entitas, terutama profitabilitas, menunjukkan berapa efektif dan efisien entitas dalam mendayagunakan sumber daya entitas $(\mid \mathrm{Al}, 2015)$. Laporan ini juga berkaitan dengan pendapatan dan biayabiaya selama periode waktu tertentu, 
misalnya bulanan atau tahunan. Komponen laba rugi menurut Darsono (2005:21) adalah:
a. Pendapatan/Penjualan
b. Harga Pokok Penjualan
c. Biaya Pemasaran
d. Biaya Administrasi dan Umum
e. Pendapatan Luar Usaha
f. Biaya Luar Usaha

3. Laporan Perubahan Ekuitas selama Periode (Statement of Charge in Equity) Laporan perubahan ekuitas yaitu suatu perubahan laporan atau mutasi laba ditahan yang merupakan bagian dari pemilik perusahaan untuk suatu periode tertentu.

4. Laporan Arus Kas selama Periode (Statement of Cash Flow)

Informasi perubahan posisi keuangan bermanfaat untuk menilai aktivitas investasi, pendanaan dan operasi selama periode pelaporan (IAI, 2015). Laporan arus kas adalah salah satu komponen neraca, yaitu kas dari satu periode berikutnya. Laporan arus kas terdiri dari tiga bagian yaitu:

a. Arus kas dari aktivasi operasi.

b. Arus kas dari aktivasi investasi.

c. Arus kas dari aktivitas pendanaan.

5. Catatan Atas Laporan Keuangan (Notes to Financial Statement)

Catatan atas laporan keuangan harus disajikan secara sistematis. Setiap pos dalam neraca, laporan laba rugi dan laporan arus kas harus berkaitan dengan informasi yang terdapat dalam catatan atas laporan keuangan. Informasi yang disajikan terkait dengan dasar penyusunan laporan keuangan dan kebijakan akuntansi spesifik serta informasi yang tidak disajikan di bagian manapun dalam laporan keuangan namun masih relevan untuk memahami laporan keuangan (IAI, 2015).

\section{Pengertian Analisis Laporan Keuangan}

Menurut Kasmir (2013:66) analisis laporan keuangan merupakan kegiatan yang dilakukan setelah laporan keuangan disusun berdasarkan data yang relevan, serta dilakukan dengan prosedur akuntansi dan penilaian yang benar, akan terlihat kondisi keuangan perusahaan yang sesungguhnya.

Menurut Harahap (2009:190), analisis laporan keuangan berarti menguraikan akun akun laporan keuangan menjadi unit informasi yang lebih kecil dan melihat hubungannya yang bersifat signifikan atau yang mempunyai makna antara yang satu dengan yang lain baik antara data kuantitatif maupun data non-kuantitatif dengan tujuan untuk mengetahui kondisi keuangan lebih dalam yang sangat penting dalam proses menghasilkan keputusan yang tepat.

\section{Pengertian Kinerja Keuangan}

Pengertian kinerja menurut Bastian (2006:274) adalah gambaran pencapaian pelaksanaan/program/kebijaksanaan dalam mewujudkan sasaran, tujuan, misi dan visi suatu organisasi. Konsep kinerja keuangan menurut Gitosudarmo dan Basri (2002:275) adalah rangkaian aktivitas keuangan pada suatu periode tertentu yang dilaporkan dalam laporan keuangan diantaranya laporan laba rugi dan neraca.

Menurut Fahmi (2011:2) kinerja keuangan adalah suatu analisis yang dilakukan untuk melihat sejauh mana suatu perusahaan telah melaksanakan dengan menggunakan aturan-aturan pelaksanaan keuangan secara baik dan benar. Kinerja perusahaan merupakan suatu gambaran tentang kondisi keuangan suatu perusahaan yang dianalisis dengan alat-alat analisis keuangan, sehingga dapat diketahui mengenai baik buruknya keadaan keuangan suatu perusahaan yang mencerminkan prestasi kerja dalam periode tertentu. Hal ini sangat penting agar sumber daya digunakan secara optimal dalam menghadapi perubahan lingkungan. 
Oleh karena itu, dapat disimpulkan bahwa penilaian kinerja keuangan merupakan salah satu cara yang dapat dilakukan oleh pihak manajemen agar dapat memenuhi kewajibannya terhadap para penyandang dana dan juga untuk mencapai tujuan yang telah ditetapkan oleh perusahaan.

\section{Rasio Keuangan}

Pengertian rasio keuangan menurut James C. Van Horne dalam Kasmir (2013) merupakan indeks yang menghubungkan dua angka akuntansi dan diperoleh dengan membagi satu angka dengan angka lainnya. Rasio keuangan digunakan untuk mengevaluasi kondisi keuangan dan kinerja perusahaan. Dari hasil rasio keuangan ini akan terlihat kondisi kesehatan perusahaan yang bersangkutan.

Menurut Harahap (2009:297), rasio keuangan merupakan angka yang diperoleh dari hasil perbandingan dari satu akun laporan keuangan dengan akun lainnya yang mempunyai hubungan yang relevan dan signifikan. Rasio keuangan ini hanya menyederhanakan informasi yang menggambarkan hubungan antara pos tertentu dengan pos lainnya. Dengan penyederhanaan ini dapat dinilai secara cepat hubungan antara pos dan dapat membandingkannya dengan rasio lain.

\section{Bentuk-bentuk Rasio Keuangan}

Analisis rasio keuangan merupakan salah satu teknik dalam menganalisa laporan keuangan yang banyak digunakan untuk menilai kinerja perusahaan karena penggunaannya yang relatif mudah. Menurut Warsono (2003:34) jenis rasio keuangan dikelompokkan menjadi:

1. Rasio likuiditas (Liquidity Ratios)

Rasio-rasio likuiditas adalah suatu rasio keuangan yang menunjukkan kemampuan perusahaan dalam memenuhi kewajibankewajiban jangka pendeknya. Pada prinsipnya, semakin tinggi rasio likuiditas, maka semakin baik kemampuan perusahaan dalam memenuhi kewajiban jangka pendeknya.

2. Rasio leverage (Leverage Ratios) Rasio leverage/utang atau solvabilitas adalah rasio keuangan yang digunakan untuk mengukur kemampuan perusahaan dalam memenuhi kewajiban-kewajiban jangka panjangnya.

3. Rasio aktivitas (Activity Ratios)

Rasio aktivitas adalah rasio keuangan yang mengukur bagaimana perusahaan secara efektif mengelola aktiva-aktivanya.

4. Rasio profitabilitas (Profitability Ratios) Rasio profitabilitas memperlihatkan pengaruh kombinasi likuiditas, aktivitas, dan leverage terhadap hasil operasi. Rasio profitabilitas mengukur seberapa besar kemampuan perusahaan dalam menghasilkan keuntungan.

5. Rasio nilai pasar (Market Value Ratios) Berdasarkan indonesian Capital Market Directory, rasio nilai pasar bagi perusahaan-perusahaan yang tercatat di Bursa Efek Jakarta dikelompokkan menjadi dua macam ukuran, yaitu data per lembar saham (per share data) dan rasio-rasio keuangan. Dari beberapa penjelasan jenisjenis rasio di atas, yang menjadi indikator dalam menganalisis kinerja keuangan perusahaan pada PT, Sepatu Bata Tbk, penelitian ini menggunakan rasio profitabilitas dan rasio aktivitas.

\section{Profitabilitas}

Profitabilitas menurut Riyanto (2001) adalah kemampuan perusahaan untuk menghasilkan laba selama periode tertentu. Sedangkan Sartono (2001) mendefinisikan profitabilitas adalah kemampuan perusahaan memperoleh laba dalam hubungannya dengan penjualan, total aktiva maupun modal sendiri. Setiap perusahaan selalu berusaha untuk meningkatkan profitabilitasnya. Jika perusahaan berhasil meningkatkan profitabilitasnya, dapat dikatakan bahwa perusahaan tersebut 
mampu mengelola sumber daya yang dimilikinya secara efektif dan efisien sehingga mampu menghasilkan laba yang tinggi. Sebaliknya, sebuah perusahaan yang memiliki profitabilitas rendah menunjukkan bahwa perusahaan tersebut tidak mampu mengelola sumber daya yang dimilikinya dengan baik, sehingga tidak mampu menghasilkan laba tinggi. Rasio Profitabilitas yaitu rasio yang digunakan untuk mengukur seberapa besar kemampuan perusahaan memperoleh laba baik dengan hubungan penjualan maupun laba rugi modal sendiri.

\section{A. Gross Profit Margin}

Gross Profit Margin (GPM) merupakan perbandingan penjualan bersih dikurangi harga pokok penjualan dengan penjualan bersih atau rasio antara laba kotor dengan penjualan bersih.

Gross Profit Margin $=\frac{\text { LabaKotor }}{\text { Penjualan }} \times 100 \%$

Rasio ini mengukur efisiensi pengendalian harga pokok atau biaya produksinya, mengindikasikan kemampuan perusahaan untuk berproduksi secara efisien. Semakin besar gross profit margin semakin baik keadaan operasi perusahaan, karena hal ini menunjukkan bahwa cost of good sold lebih rendah dibandingkan dengan penjualan.

\section{B. Net Profit Margin}

Net Profit Margin (NPM) merupakan rasio antara laba (net profit) yaitu penjualan sesudah dikurangi dengan seluruh biaya termasuk pajak dibandingkan dengan penjualan.

Net Profit Margin $=\frac{\text { LabaBersih }}{\text { Penjualan }} \times 100 \%$

NPM mengukur laba yang dihasilkan oleh setiap satu rupiah penjualan. Rasio ini memberi gambaran tentang laba untuk para pemegang saham sebagai persentase dari penjualan serta mengukur seluruh efisiensi, baik produksi, administrasi, pemasaran, pendanaan, penentuan harga maupun manajemen pajak. Rasio ini menunjukkan seberapa besar persentase pendapatan bersih yang diperoleh dari setiap penjualan, karena memiliki kemampuan yang tinggi untuk mendapatkan laba. Meskipun rasio ini diharapkan tinggi, akan tetapi karena adanya kekuatan persaingan industri, kondisi ekonomi, pendanaan utang dan karakteristik operasi, maka rasio ini biasanya berbeda di antara perusahaan.

\section{Return On Investment}

Return On Investment (ROI) merupakan pengukuran kemampuan perusahaan secara keseluruhan dalam menghasilkan keuntungan dengan menjumlah keseluruhan aktiva yang tersedia di dalam perusahaan. Semakin tinggi rasio ini, maka semakin baik keadaan suatu perusahaan karena keseluruhan aktiva perusahaan memiliki kemampuan yang tinggi untuk memperoleh laba.

Return On Inverstment $=\frac{\text { Laba Bersih }}{\text { Total Aktiva }} \times 100 \%$

\section{Aktivitas}

Aktivitas adalah suatu peristiwa atau kejadian yang pada umumnya tidak dilakukan secara terus menerus. Dalam kamus besar Bahasa Indonesia, aktivitas adalah suatu kegiatan, usaha, pekerjaan atau kekuatan dan ketangkasan. UU RI No. 15 Tahun 2006 juga menyimpulkan personel (sumber daya manusia), barang modal termasuk peralatan dan teknologi, dana atau kombinasi dari beberapa atau semua jenis sumber daya tersebut sebagai masukan (input) untuk menghasilkan keluaran (output) dalam bentuk barang atau jasa.

Rasio aktivitas yaitu untuk mengetahui sejauh mana efesiensi perusahaan

JIMFE (Jurnal Ilmiah Manajemen Fakultas Ekonomi)

Volume 3 No. 2 Tahun 2017, Hal. 14-27 
sehubungan dengan pengelolaan aset perusahaan untuk memperoleh penjualan.

\section{A. Perputaran Piutang (Receivable Turnover)}

Tingkat perputaran piutang (Receivable Turnover) dapat dicari dengan cara membagi total penjualan kredit dengan piutang ratarata.

Receivable Turnover $=\frac{\text { Penjualan }}{\text { Rata }- \text { Rata Piutang }}$

Rasio ini menunjukkan seberapa cepat penagihan piutang. Semakin besar angka yang dihasilkan maka akan semakin baik pengelolaan piutang.

\section{B. Perputaran Persediaan (Inventory \\ Turnover)}

Perputaran persediaan dihitung dengan cara membagi harga pokok penjualan (cost of good sold) dengan rata-rata persediaan.

Inventory Turnover $=\frac{\text { Harga Pokok Penjualan }}{\text { Rata }- \text { Rata Persediaan }}$

Rasio ini menunjukkan seberapa cepat perputaran persedian dalam siklus produksi normal. Semakin besar rasio ini semakin baik karena dianggap bahwa kegiatan penjualan berjalan dengan cepat.

\section{Perputaran Total Aktiva (Total Asset Turnover) \\ Perputaran total aktiva (Total Asset} Turnover) mengukur perputaran dari semua aset yang dimiliki perusahaan. Perputaran total aktiva (total asset turnover) dapat dicari dengan cara membagi penjualan dengan total asetnya.

Total Asset Turnover $=\frac{\text { Penjualan }}{\text { Rata }- \text { RataAktiva }}$

Rasio ini menunjukkan efektivitas penggunaan seluruh harta perusahaan dalam rangka menghasilkan penjualan atau menggambarkan berapa rupiah penjualan bersih yang dapat dihasilkan oleh setiap rupiah yang diinvestasikan dalam bentuk harta perusahaan. Kalau perputarannya lambat, hal ini menunjukkan bahwa aktiva yang dimiliki terlalu besar dibandingkan dengan kemampuan untuk menjual.

\section{METODE PENELITIAN}

Objek dalam penelitian ini adalah PT Bata Tbk. Laporan keuangan publikasi yang digunakan adalah data laporan keuangan selama 4 tahun berturut-turut yaitu dari tahun 2013 sampai dengan tahun 2016 dan yang berakhir 31 Desember. Pengambilan data berasal dari data laporan keuangan PT Bata Tbk yang tercantum dalam situs BEI.

Guna mendukung penelitian ini digunakan studi kepustakaan yaitu segala usaha yang dilakukan oleh peneliti untuk menghimpun informasi yang relevan dengan topik atau masalah yang akan atau sedang diteliti.

Menurut jenis data dan analisis, penelitian ini termasuk penelitian kuantitatif. Penelitian kuantitatif mencakup setiap penelitian yang didasarkan atas perhitungan persentase, rata-rata dan perhitungan statistik lainnya. Dengan kata lain, penelitian kuantitatif melibatkan diri pada perhitungan angka atau kuantitas. Hasil analisis kuantitatif cenderung membuktikan maupun memperkuat teori-teori yang sudah ada.

PT Bata Tbk merupakan perusahaan yang sudah go public, maka metode yang digunakan dalam menilai kinerja keuangan perusahaan adalah dengan menggunakan metode lintas waktu (time series).

A. Rasio Profitabilitas

1. Jika GPMt > GPMt-1, maka kinerja keuangan perusahaan dapat dinyatakan baik.

2. Jika NPMt > NPMt-1, maka kinerja keuangan perusahaan dapat dinyatakan baik. 
3. Jika ROIt $>$ ROIt-1, maka kinerja keuangan perusahaan dapat dinyatakan baik.

Keterangan :

GPMt: Gross Profit Margin pada periode tahun ke-t

GPMt-1: Gross Profit Margin pada periode tahun ke-t-1

NPMt: Net Profit Margin pada periode tahun ke-t

NPMt-1: Net Profit Margin pada periode tahun ke-t-1

ROIt: Return on Investment pada periode tahun ke-t

ROIt-1: Return on Investment pada periode tahun ke-t-1

B. Rasio Aktivitas

1. Jika RTt > RTt-1, maka kinerja keuangan perusahaan dapat dinyatakan baik.

2. Jika ITt > ITt-1, maka kinerja keuangan perusahaan dapat dinyatakan baik.

3. Jika TATt > TATt-1, maka kinerja keuangan perusahaan dapat dinyatakan baik.

Keterangan :

RTt: Receivable Turnover pada periode tahun ke-t

RTt-1: Receivable Turnover pada periode tahun ke-t-1

ITt: Inventory Turnover pada periode ke- $\mathrm{t}$

ITt-1: Inventory Turnover pada periode ke-t-1 TATt: Total Asset Turnover pada periode ke-t TATt-1: Total Asset Turnover pada periode ke$\mathrm{t}-1$

\section{HASIL DAN PEMBAHASAN}

\section{Perhitungan Rasio Profitabilitas}

A. Gross Profit Margin

GPM merupakan perbandingan

penjualan bersih dikurangi harga pokok penjualan dengan penjualan bersih atau rasio antara laba kotor dengan penjualan bersih.

Rasio ini mengukur efisiensi pengendalian harga pokok atau biaya produksinya, mengindikasikan kemampuan perusahaan untuk berproduksi secara efisien.
Semakin besar gross profit margin semakin baik keadaan operasi perusahaan, karena hal ini menunjukkan bahwa cost of good sold lebih rendah dibandingkan dengan penjualan.

Gross Profit Margin Tahun $2014=\frac{450.499 .586}{1.008 .727 .515} \times 100 \%=44,66 \%$

Gross Profit Margin Tahun 2015 $=\frac{406.751 .383}{1.028 .850 .578} \times 100 \%=39,53 \%$

Gross Profit Margin Tahun 2016 $=\frac{431.451 .220}{999.802 .379} \times 100 \%=43,15 \%$

Berdasarkan hasil perhitungan, gross profit margin pada tahun 2014 sebesar $44,66 \%$, artinya setiap 1 rupiah penjualan menghasilkan laba sebesar Rp0,4466, sedangkan pada tahun 2015 gross profit margin sebesar $39,53 \%$ yang artinya setiap 1 rupiah penjualan menghasilkan laba sebesar Rp0,3953 dan pada tahun 2016 gross profit margin sebesar $43,15 \%$ yang artinya setiap 1 rupiah penjualan menghasilkan laba sebesar Rp0,4315. Berdasarkan hasil perhitungan di atas menunjukkan gross profit margin pada tahun 2015 mengalami penurunan sebesar $5,13 \%$ yang disebabkan oleh penurunan laba kotor dan diikuti dengan peningkatan penjualan. Pada tahun 2016 gross profit margin mengalami peningkatan kembali sebesar 3,62\%, hal ini disebabkan oleh peningkatan laba kotor yang diikuti oleh penurunan penjualan. Terlihat juga bahwa kinerja operasional perusahaan dilihat dari gross profit margin berfluktuasi, yaitu pada tahun 2015 nilai gross profit margin menurun dari tahun 2014 dan pada tahun 2016 nilainya mengalami kenaikan dari tahun 2015. Dari perhitungan di atas dapat diketahui bahwa kinerja operasional perusahaan ini kurang baik karena nilai gross profit marginnya pada tahun 2015 dan 2016 lebih rendah dari pada tahun dasarnya yaitu tahun 2014. Hal ini menandakan bahwa perusahaan tersebut rawan terhadap perubahan harga, baik harga jual maupun

JIMFE (Jurnal Ilmiah Manajemen Fakultas Ekonomi)

Volume 3 No. 2 Tahun 2017, Hal. 14-27 
harga pokok, ini berarti bahwa apabila terjadi perubahan pada harga jual atau harga pokok, perubahan ini akan sangat berpengaruh terhadap laba perusahaan.

\section{B. Net Profit Margin}

NPM merupakan rasio antara laba (net profit) yaitu penjualan sesudah dikurangi dengan seluruh biaya termasuk pajak dibandingkan dengan penjualan.

Rasio ini menunjukkan seberapa besar persentase pendapatan bersih yang diperoleh dari setiap penjualan, karena memiliki kemampuan yang tinggi untuk mendapatkan laba.

Net Profit Margin Tahun $2014=\frac{71.246 .429}{1.008 .727 .515} \times 100 \%=7,06 \%$

Net Profit Margin Tahun $2015=\frac{129.519 .446}{1.028 .850 .578} \times 100 \%=12,59 \%$

Net Profit Margin Tahun 2016 $=\frac{42.231 .663}{999.802 .379} \times 100 \%=4,22 \%$

Berdasarkan hasil perhitungan net profit margin pada tahun 2014 sebesar $7.06 \%$ yang artinya setiap Rp1 penjualan menghasilkan keuntungan sebesar Rp0,0706. Pada tahun 2015 net profit margin sebesar 12,59\% yang artinya setiap Rp1 penjualan menghasilkan keuntungan sebesar Rp0,1259, sedangkan pada tahun 2016 sebesar 4,22\% yang artinya setiap Rp1 penjualan menghasilkan keuntungan sebesar Rp0,0422. Berdasarkan dari perhitungan di atas menunjukkan bahwa net profit margin tahun 2015 mengalami peningkatan sebesar $5,53 \%$ hal ini disebabkan adanya peningkatan laba bersih dan diikuti oleh peningkatan penjualan. Sedangkan pada tahun 2016 net profit margin mengalami penurunan yang sangat drastis sebesar $8,37 \%$ dari tahun sebelumnya, hal ini disebabkan karena adanya penurunan laba bersih dan diikuti dengan penurunan penjualan yang sangat drastis. Maka dapat disimpulkan bahwa kinerja perusahaan kurang baik karena
NPM terjadi fluktuasi yang sangat tajam terutama jika kita lihat dari tahun 2015 ke tahun 2016 terjadi penurunan kinerja yang sangat drastis, hal ini dikarenakan tingkat penjualan yang terjadi dalam tahun 2016 tidak seimbang dengan tingkat biaya yang digunakan, jadi untuk dapat meningkatkan kinerja operasional perusahaan maka harus dapat menekan biaya usaha guna memperoleh tingkat penjualan yang sangat di dalam menghasilkan laba.

\section{Return On Investment}

Return on investment merupakan pengukuran kemampuan perusahaan secara keseluruhan dalam menghasilkan keuntungan dengan menjumlah keseluruhan aktiva yang tersedia di dalam perusahaan. Semakin tinggi rasio ini, maka semakin baik keadaan suatu perusahaan karena keseluruhan aktiva perusahaan memiliki kemampuan yang tinggi untuk memperoleh laba.

Return On Investment Tahun $2014=\frac{71.246 .429}{774.891 .087} \times 100 \%=9,19 \%$

Return On Investment Tahun $2015=\frac{129.519 .446}{795.257 .974} \times 100 \%=16,29 \%$

Return On Investment Tahun $2016=\frac{42,231.663}{804.742 .917} \times 100 \%=5,25 \%$

Berdasarkan hasil perhitungan menunjukkan bahwa return on investment pada tahun 2014 sebesar 9,19\%, artinya setiap Rp1 modal yang diinvestasikan dalam keseluruhan aktiva dapat menghasilkan keuntungan sebesar Rp0,0919. Return on investment pada tahun 2015 sebesar 16,29\% yang dapat diartikan bahwa setiap Rp1 modal yang diinvestasikan dalam keseluruhan aktiva dapat menghasilkan keuntungan sebesar Rp 0,1629, sedangkan pada tahun 2016 return on investment sebesar $5,25 \%$ artinya setiap $\mathrm{Rp} 1$ modal yang diinvestasikan dalam keseluruhan aktiva dapat menghasilkan keuntungan sebesar Rp0,0525. 
Pada tahun 2015 return on investment menunjukkan peningkatan sebesar 7,1 \% hal ini disebabkan oleh peningkatan laba bersih setelah pajak dan diikuti oleh peningkatan total aktiva. Sedangkan pada tahun 2016 return on investment mengalami penurunan sebesar $11,04 \%$ hal tersebut disebabkan oleh adanya tingkat penurunan laba bersih dan diikuti oleh peningkatan total aktiva. Juga dapat diketahui bahwa ROI yang dperoleh itu masih sama terjadi fluktuasi, sehingga dapat disimpulkan bahwa tingkat ROI akan meningkat jika laba bersih yang dihasilkan tinggi dan tingkat penggunaan aktiva yang rendah. Hal ini juga tentunya didukung dengan tingkat penjualan yang tinggi dengan menekan sejumlah biaya usaha yang dikeluarkan.

\section{Perhitungan Rasio Aktivitas}

Rasio aktivitas mengukur bagaimana perusahaan secara efektif mengelola aktivaaktivanya pada tingkat kegiatan tertentu. Untuk menganalisis tingkat aktivitas pada PT Bata Tbk, maka penulis menggunakan laporan keuangan selama tiga periode yaitu dari tahun 2014 sampai dengan 2016.

\section{A. Perputaran Piutang (Receivable Turnover)}

Tingkat perputaran piutang (Receivable Turnover) dapat dicari dengan cara membagi total penjualan dengan piutang rata-rata.

\section{Receivable Turnover Tahun $2014=$ $\frac{1.008 .727 .515}{(31.583 .112+22.014 .249) / 2}=37,64$}

\section{Receivable Turnover Tahun $2015=$ $\frac{1.028 .850 .578}{(22.014 .249+27.067 .308) / 2}=41,92$}

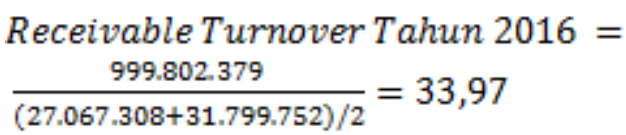

Berdasarkan hasil perhitungan menunjukkan bahwa pada tahun 2014 receivable turnover sebesar 37,64 kali, itu artinya rata-rata dana yang tertanam dalam piutang berputar 37,64 kali selama satu tahun, pada tahun 2015 receivable turnover sebesar 41,92 kali yang artinya rata-rata dana yang tertanam dalam piutang berputar 41,92 kali selama satu tahun. Pada tahun 2016 receivable turnover sebesar 33.97 kali, artinya rata-rata dana yang tertanam dalam piutang berputar 33,97 kali selama satu tahun. Peningkatan receivable turnover pada tahun 2015 sebesar 4,28 kali, hal ini disebabkan oleh peningkatan hasil penjualan dan diikuti penurunan rata-rata piutang. Penurunan receivable turnover pada tahun 2016 sebesar 7,95 kali, hal ini disebabkan oleh penurunan hasil penjualan dan peningkatan rata-rata piutang.

Receivable turnover terjadi fluktuasi dari tahun 2014 sampai dengan 2016, hal ini disebabkan oleh tingkat pengembalian piutang yang tidak tepat waktu sehingga menyebabkan terjadi fluktuasi tersebut.

\section{B. Perputaran Persediaan (Inventory Turnover)}

Perputaran persediaan dihitung dengan cara membagi harga pokok penjualan (cost of good sold) dengan rata-rata persediaan.

Rasio ini menunjukkan seberapa cepat perputaran persedian dalam siklus produksi normal. Semakin besar rasio ini semakin baik karena dianggap bahwa kegiatan penjualan berjalan dengan cepat.

$$
\begin{aligned}
& \text { Inventory Turnover Tahun } 2014= \\
& \frac{558.227 .929}{(281.405 .718+314.628 .156) / 2}=1,87
\end{aligned}
$$

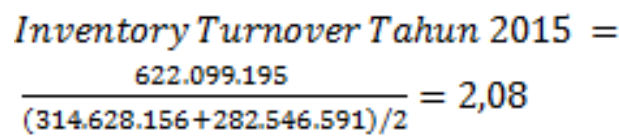




\section{Inventory Turnover Tahun $2016=$ $\frac{568.351 .159}{(282.546 .591+324.917 .517) / 2}=1,87$}

Berdasarkan hasil perhitungan menunjukkan bahwa pada tahun 2014 inventory turnover sebesar 1,87 kali, artinya dana yang tertanam dalam persediaan ratarata 1,87 kali dalam setahun. Pada tahun 2015 inventory turnover sebesar 2,08 kali, artinya dana yang tertanam dalam persediaan sebesar 2,08 kali dalam setahun. Pada tahun 2016 inventory turnover sebesar 1,87 kali, ini artinya dana yang tertanam dalam rata-rata persediaan sebesar 1,87 kali dalam setahun. Peningkatan inventory turnover pada tahun 2015 sebesar 0,21 kali, hal ini disebabkan oleh peningkatan harga pokok penjualan diikuti oleh peningkatan rata-rata persediaan. Penurunan inventory turnover pada tahun 2016 sebesar 0,21 kali disebabkan oleh penurunan harga pokok penjualan diikuti oleh peningkatan rata- rata persediaan.

Berdasarkan hasil perhitungan di atas rasio ini menunjukkan perputaran persediaan yang tidak baik karena berisiko terjadinya kekurangan persediaan dan proses produksi berjalan dengan lambat.

\section{Perputaran Total Aktiva (Total Asset Turnover) \\ Perputaran total aktiva (total asset} turnover) mengukur perputaran dari semua aset yang dimiliki perusahaan.

\section{Total Asset Turnover Tahun $2014=$ 1.008.727.515 \\ $\frac{1680.685 .060+774.891 .087) / 2}{(2,39}$}

Total Asset Turnover Tahun $2015=$

$\frac{1.028 .850 .578}{(774.891 .087+795.257 .974) / 2}=1,31$
Total Asset Turnover Tahun $2016=$

$\frac{999.802 .379}{(795.257 .974+804.742 .917) / 2}=1,25$

Berdasarkan hasil perhitungan menunjukkan bahwa pada tahun 2014 total asset turnover sebesar 1,39 kali, artinya dana yang tertanam pada keseluruhan aktiva ratarata dalam satu tahun berputar 1,39 kali. Pada tahun 2015 total asset turnover sebesar 1,31 kali, artinya dana yang tertanam pada keseluruhan aktiva rata-rata dalam satu tahun berputar 1,31 kali. Pada tahun 2016 total asset turnover sebesar 1,25 kali, artinya dana yang tertanam pada keseluruhan aktiva rata-rata dalam satu tahun berputar 1,25 kali. Dapat dikatakan juga bahwa total asset turnover perusahaan kurang baik, hal ini dapat diketahui dengan melihat adanya penurunan perputaran total aktiva pada tahun 2014 sampai dengan 2016 hal ini disebabkan oleh tingkat penjualan yang diperoleh mengalami penurunan tidak diimbangi dengan biaya usaha yang dikeluarkan walaupun total aktiva mengalami peningkatan.

\section{Penilaian Kinerja Keuangan Perusahaan}

Berdasarkan tabel di bawah ini dapat diketahui kinerja keuangan PT Bata Tbk periode tahun 2014-2016 dengan membandingkan hasil perhitungan rasio-rasio keuangan secara time series.

Tabel 2

Analisis Rasio Profitabilitas dan Rasio Aktivitas PTBata Tbk Periode 2014-2016

\begin{tabular}{|c|c|c|c|}
\hline Tahun & 2014 & 2015 & 2016 \\
\hline \multicolumn{4}{|l|}{ Rasio Profitabilitas } \\
\hline $\begin{array}{ll}\text { Gross } & \text { Profit } \\
\text { Margin } & \end{array}$ & $44,66 \%$ & $39,53 \%$ & $43,15 \%$ \\
\hline $\begin{array}{ll}\text { Net } & \text { profit } \\
\text { Margin } & \\
\end{array}$ & $7,06 \%$ & $12,59 \%$ & $4,22 \%$ \\
\hline $\begin{array}{ll}\text { Return } & \text { On } \\
\text { Investment } & \end{array}$ & $9,19 \%$ & $16,29 \%$ & $5,25 \%$ \\
\hline $\begin{array}{l}\text { Rata-rata Rasio } \\
\text { Profitabilitas }\end{array}$ & $20,30 \%$ & $22,80 \%$ & $17,54 \%$ \\
\hline \multicolumn{4}{|l|}{ Rasio Aktivitas } \\
\hline $\begin{array}{l}\text { Receivable } \\
\text { Turnover }\end{array}$ & $\begin{array}{l}37,64 \\
\text { Kali }\end{array}$ & $\begin{array}{l}41,92 \\
\text { Kali }\end{array}$ & 33,97Kali \\
\hline
\end{tabular}

JIMFE (Jurnal Ilmiah Manajemen Fakultas Ekonomi) Volume 3 No. 2 Tahun 2017, Hal. 14-27 


\begin{tabular}{|l|l|l|l|}
\hline $\begin{array}{l}\text { Inventory } \\
\text { Turnover }\end{array}$ & 1,87 Kali & 2,08 Kali & 1,87 Kali \\
\hline $\begin{array}{l}\text { Total Asset } \\
\text { Turnover }\end{array}$ & 1,39 Kali & 1,31 Kali & 1,25 Kali \\
\hline $\begin{array}{l}\text { Rata-Rata Rasio } \\
\text { Aktivitas }\end{array}$ & $\begin{array}{l}\mathbf{1 3 , 6 3} \\
\text { Kali }\end{array}$ & $\begin{array}{l}\mathbf{1 5 , 1 0} \\
\text { Kali }\end{array}$ & $\mathbf{1 2 , 3 6 ~ K a l i}$ \\
\hline
\end{tabular}

\section{Rasio Profitabilitas}

A. Gross Profit Margin

\section{$44,66 \%(2014)>39,53 \%(2015)<43,15 \%$ (2016)}

Gross profit margin pada tahun 2014 menunjukkan kinerja keuangan perusahaan yang baik sedangkan pada tahun 2015 dan 2016 menunjukkan kinerja keuangan perusahaan yang kurang baik.

\section{B. Net Profit Margin}

$7,06 \%(2014)<12,59 \%(2015)>4,22 \%(2016)$

Net profit margin pada tahun 2014 dan 2016 menunjukkan kinerja keuangan perusahaan yang kurang baik sedangkan pada tahun 2015 menunjukkan kinerja keuangan perusahaan yang baik.

\section{Return On Investment}

\section{$9,19 \%(2014)<16,29 \%(2015)>5,25 \%(2016)$}

Return on investment pada tahun 2014 dan 2016 menunjukkan kinerja keuangan perusahaan yang kurang baik sedangkan pada tahun 2015 menunjukkan kinerja keuangan perusahaan yang baik.

Jika dilihat dari perhitungan tiap-tiap rasio profitabilitas pada tabel 2, kinerja keuangan perusahaan mengalami fluktuasi dari tahun ke tahun, tetapi jika dilihat dari rata-rata rasio profitabilitas, kinerja keuangan perusahaan pada tahun 2015 secara keseluruhan adalah baik walaupun pada perhitungan net profit margin sempat menurun di tahun 2015. Pada tahun 2014 dan 2016 mengalami penurunan dan penurunan paling drastis bisa kita lihat pada tahun 2016 sehingga dapat dikatakan kinerja keuangan perusahaan berdasarkan rasio profitabilitas adalah kurang baik. Dapat diartikan bahwa kemampuan perusahaan dalam memperoleh laba pada tahun 2014 dan 2016 adalah tidak efektif.

\section{Rasio Aktivitas}

A. Receivable Turnover

37,64 kali $(2014)<41,92$ kali $(2015)>33,97$ kali (2016)

Receivable turnover pada tahun 2014 dan 2016 mengalami perputaran yang sangat lambat dalam setahun. Ini menunjukkan bahwa perputaran piutang sangat lama yang dikarenakan customer membayar tagihan tidak tepat waktu dan piutang tidak bisa secepatnya dijadikan uang. Tetapi di tahun 2015 perputaran piutang sangat baik dalam setahun, hal ini terjadi karena perusahaan mengembalikan piutang lebih cepat dengan menambah penjualan kredit bersih.

\section{B. Inventory Turnover}

\section{1,87 kali $(2014)<2,08$ kali $(2015)>1,87$ kali (2016)}

Inventory turnover pada tahun 2014 dan tahun 2016 mengalami perputaran sama serta stabil hanya saja kurang baik jika dibandingkan dengan tahun 2015. Hal ini menunjukkan bahwa kinerja keuangan perusahaan pada tahun 2015 adalah baik karena perputaran persediaan untuk proses produksi berputar sangat cepat dan dapat berisiko adanya kekurangan persediaan di gudang.

C. Total Asset Turnover

1,39 kali (2014) > 1,31 kali (2015) > 1,25 kali (2016)

JIMFE (Jurnal Ilmiah Manajemen Fakultas Ekonomi)

Volume 3 No. 2 Tahun 2017, Hal. 14-27 
Total asset turnover pada tahun 2014 paling besar dibandingkan tahun 2015 dan 2016. Kalau perputarannya cepat, hal ini menunjukkan bahwa kemampuan menjual lebih besar jika dibanding dengan aktiva yang dimiliki.

Kinerja keuangan perusahaan yang paling baik adalah tahun 2015. Jika dilihat dari perhitungan tiap-tiap rasio aktivitas maupun dari rata-rata rasio. Hal ini disebabkan oleh tingginya nilai penjualan pada tahun tersebut.

Kinerja keuangan perusahaan pada tahun 2014 masih di atas tahun 2016, karena pada tahun 2016 mengalami penurunan yang disebabkan oleh penurunan penjualan dan diikuti oleh kenaikan rata-rata persediaan dan rata-rata total aktiva. Sehingga dapat dikatakan kinerja keuangan perusahaan adalah kurang baik. Dengan kata lain perusahaan tidak efektif mengelola aktiva-aktivanya pada tahun 2016.

Berdasarkan hasil analisis dan perhitungan kinerja keuangan dengan menggunakan rasio profitabilitas dan rasio aktivitas, secara keseluruhan kinerja keuangan PT Bata Tbk belum dikatakan baik karena bisa kita lihat dari perolehan tingkat laba, total aktiva maupun dari tingkat penjualan yang dicapai mengalami fluktuasi dan cenderung tidak ada peningkatan yang signifikan. Pada tahun 2015 kinerja keuangan menunjukkan kondisi yang baik namun pada tahun 2014 dan 2016 terjadi penurunan sangat drastis. Perlu dilakukan suatu bentuk evaluasi lebih mendalam guna memperbaiki kinerja keuangan yang ada dengan menerapkan strategi usaha supaya tingkat laba maupun pengelolaan aktiva meningkat.

\section{KESIMPULAN DAN SARAN}

Kinerja keuangan PT Bata Tbk selalu berfluktuasi setiap tahunnya. Dapat kita lihat pada kemampuan perusahaan dalam menggunakan modalnya untuk memperoleh laba yang menunjukan kinerja keuangan yang cukup baik pada tahun 2015 dibandingkan dengan tahun sebelumnya. Walaupun demikian angka GPM untuk tahun 2015 menunjukkan penurunan karena di tahun ini perusahaan mengalami penurunan laba meski sisi penjualan mengalami peningkatan. Pihak perusahaan sepertinya tidak mampu menekan biaya usaha yang dikeluarkan. Secara keseluruhan kinerja keuangan dengan menggunakan rasio profitabilitas juga menunjukkan belum efisien.

Mengacu pada rasio aktivitas PT Bata Tbk, di tahun 2015 kinerja cukup efisien karena adanya pengembalian piutang yang sangat cepat oleh pihak perusahaan dan adanya perputaran pesediaan yang sangat cepat dalam proses produksi. Begitu juga penjualan yang mengalami peningkatan jika dibandingkan dengan pengelolaan aktivanya. Sedangkan pada tahun 2016 terjadi penurunan jumlah penjualan, maupun tingkat pengelolaan aktivanya.

Rasio profitabilitas dan rasio aktivitas saling berpengaruh satu sama lain. Dengan adanya rasio profitabilitas perusahaan dapat menilai kinerjanya dalam menghasilkan laba atas penggunaan sejumlah modal dan aktiva yang dikelola dan dimilikinya. Dan dengan rasio aktivitas perusahaan dapat mengetahui pengelolaan aktiva perusahaan secara maksimal untuk menghasilkan keuntungan dari penjualan yang dilakukan.

Sebagai saran perusahaan harus selalu melakukan evaluasi dalam melakukan proses bisnisnya terutama pada tahap pengendalian manajemen. Rasio profitabilitas dan rasio aktivitas dapat digunakan sebagai salah satu alat pengukuran kinerja keuangan dalam meningkatkan kemampuan perusahaan melakukan penjualan dan menghasilkan laba.

\section{DAFTAR PUSTAKA}

Kasmir, 2013. "Analisis Laporan Keuangan". Edisi 1, Cetakan ke-6 Jakarta: Rajawali Pers. 
Munawir, 2004. Analisis Laporan Keuangan. Cetakan Kelima, Liberty, Yogyakarta.

Harahap, Sofyan Syafry. 2009. "Analisis krisis Atas Laporan Keuangan". Jakarta: Raja Grafindo Persada.

Brigham dan Houston. 2010. Dasar Dasar Manajemen Keuangan, Buku 1. (Edisi 11). Jakarta : Salemba Empat.

Subramanyam, KR dan John, J. Wild, 2010. Analisis Laporan Keuangan, Buku Satu, Edisi Sepuluh , Salemba Empat, Jakarta.

Fahmi, Irham. 2010. Analisis Laporan Keuangan, Lampulo : Alfabeta.

Darsono, 2005. Pedoman Praktis Memahami Laporan Keuangan. Edisi pertama. Andi: Yogyakarta.

Munawir, 2010. Analisis Laporan Keuangan. Konsep dan Aplikasi, Penerbit Yogyakarta.

Bastian, Indra dan Suhardjono., 2006. Akuntansi Perbankan, Salemba Empat, Jakarta.
Gitosudarmo, Indriyo., dan Basri. 2002. Manajemen Keuangan. BPFE : Yogyakarta.

Warsono, M. M. 2003. Manajemen Keuangan Perusahaan, Jilid Satu, Edisi Tiga, Cetakan Pertama, Bayumedia Publishing, Malang.

Riyanto, Bambang. 2001. Dasar-Dasar Pembelanjaan Perusahaan, Edisi Keempat, Cetakan Ketujuh, BPFE, Yogjakarta.

Sartono, Agus, 2001. Manajemen Keuangan Internasional, BPFE : Yogyakarta.

Djarwanto, PS. 2001. Pokok-Pokok Analisa Laporan Keuangan, Edisi Pertama, Cetakan ke delapan, BPFE Yogyakarta.

Ikatan Akuntansi Indonesia, 2015. Standar Akuntansi Keuangan. Penerbit : Salemba Empat, Jakarta.

JIMFE (Jurnal Ilmiah Manajemen Fakultas Ekonomi)

Volume 3 No. 2 Tahun 2017, Hal. 14-27 